\title{
HAKKÂRI’DE TESPIT EDILEN ŞEL ŞEPIK ÖRNEKLERININ TEKNIK VE DESEN ÖZELLIKLERININ INCELENMESi
}

\author{
ANALYSIS OF TECHNICAL AND PATTERN PROPERTIES OF THE SAMPLES OF ŞEL ŞEPIK \\ DETECTED IN HAKKÂRI
}

\author{
ilker Öztürk ${ }^{*}$
}

\section{Öz}

Hakkâri'de geleneksel ve kendilerine özgü yöresel giyim kuşamın halen devam ettiği görülmektedir. Merkezde, ilçelerde ve köylerde Şel şepik denilen erkek kıyafetleri günlük yaşamda ve özel günlerde kullanılmaktadır. Araştırmanın kavramsal çerçevesinde Hakkâri'de giyilen geleneksel erkek kıyafeti Şel şepik'in günümüze kadar gelen tarihi gelişimi, geleneksel törenlerde kullanımı üzerinde durulmuştur. Kıyafetlerin üretiminde kullanılan hammadde, tezgâh tipi, renk ve desen zenginliği tespit edilerek yörede gün geçtikçe önemini kaybeden bu kıyafetin tespit edilmesi amaçlanmıştır.

Çalışma; literatür taraması ve alan araştırması yöntemi ile gerçekleştirilmiştir. Sözlü görüşmelerden ve görsellerden elde edilen veriler neticesinde bilgi formları oluşturularak değerlendirilmiştir.

Anahtar Kelimeler: Dokuma, Hakkâri, Şel, Şepik.

\section{Abstract}

It is seen that traditional and unique local clothing still continues in Hakkâri. In the center, districts and villages, men's clothing called as Şel şepik is still used in daily life and on special occasions. In the conceptual framework of the research, the historical development of Şel şepik, the traditional male dress worn in Hakkâri, and its use in traditional ceremonies are emphasized. The raw material used in the production of the clothes, loom type, color and pattern richness was determined and it was aimed to determine this garment, which has lost its importance day by day in the region.

This study was carried out with the method of literature review and fieldwork. By taking into account the data obtained from oral interviews and visuals, information forms created and evaluated.

Keywords: Weaving, Hakkâri, Şel, Şepik.

\section{Giriş}

“El sanatlarımızın köklü geçmişinde Anadolu'daki zengin örnekleri ile dokumacılık önemli bir yer tutmaktadır. Dokuma insanların korunma, örtünme, barınma, ihtiyaçlarından doğmuştur. Zamanla temel intiyaçları karşılamanın yanında çeşitli elyafların ve tekniklerin kullanımı ile çeşitlilik göstermiştir" (Akpınarlı ve Ortaç, 2007:80).

Araştırma Makalesi // Başvuru tarihi: 24.04.2021 - Kabul tarihi: 02.06.2021.

* Doktor Öğretim Üyesi, Süleyman Demirel Üniversitesi, Güzel Sanatlar Fakültesi, Geleneksel Türk Sanatları Bölümü, ilkerozturk@sdu.edu.tr, https://orcid.org/0000-0002-0179-6835. 


\section{SDÜ ART-E}

Güzel Sanatlar Fakültesi Sanat Dergisi

Haziran'21 Cilt:14 Sayı:27

ISSN 1308-2698

Bu çeşitlilik içinde yer alan kumaşlar, günlük ve özel günlerde kullanılan çeşitli ihtiyaç ürünlerin yapımında, giyim ve kuşamda kullanılmaktadır. El dokuması kumaş; Anadolu’nun bazı bölgelerinde özellikle geleneksel yaşamın devam ettiği yerlerde kendine has yöresel erkek, kadın ve gençlerin giydikleri kıyafetlerin meydana gelmesinde en önemli temel malzemedir.

Yöresel kıyafetler "Türk kültürünün en zengin ve gösterişli dallarından biridir. Yöresel giysi denildiği zaman, dünyada birçok milletin benimsediği milletlerarası giysi, moda giysiler dışında; her milletin tarihinden gelen, günümüzde sadece halk oyunları ekiplerinin üzerinde görülen veya bazı köylerde yaşatılan, çoğu müze vitrinlerine kaldırılmış giysilerden anlaşılmaktadır" (Tan, 1992:15).

Yöresel kıyafetler için tercih edilen kumaş; bazen dokumanın yapıldığı yerin, bazen de yapımında kullanılan malzemenin adını almaktadır. Anadolu'nun birçok bölgesinde geçmişten günümüze kumaş dokumacılığı; farklı malzeme, renk, motif, desen kompozisyonu ile farklı tezgâhlarda üretilmektedir. Üretilen bu dokumalardan biri de Şel şepik kumaşıdır. Şel şepik ülkemizde daha çok Doğu ve Güneydoğu Anadolu bölgelerinde erkekler tarafından giyilen yöresel bir kıyafete verilen isimdir. Bu kıyafet ile ilgili Doğu ve Güneydoğu Anadolu bölgelerinde yapılan çalışmalar incelendiğinde "Şel şepik, Şeli Şepik, Şelü Şepık, Şal şapık, Şal şapik, Şaladihyani" gibi benzer isimler ile telaffuz edildiği anlaşılmaktadır.

“Doğu ve Güney Doğu Anadolu Bölgelerinde kırsal kesiminde özellikle kapalı ekonominin hâkim olduğu alanlarda geleneksel anlamda üretilen şal-şapik dokuması dokunduğu kıl ve ipe verilen "Gej" adı ile adlandırılmaktadır" (Çelebi, 2002:39). "Bu dokuma keçi kılından yapıldığı için “Gej” ismini almıştır” (Çelik, 2006:343).

Şel şepik kumaş dokumasının başlangıç tarihi kesin olarak bilinmemektedir. Ancak "Bitlis Beyi Şeref Han'ın şal-şapık (Gej) dokumasından yapılmış elbiseli görüntüsü bu sanatın 15. yy.'dan önce yörede varlığını göstermektedir" (Çelebi, 2002:40).

Güney Anadolu'da il ve ilçe merkezi olmak üzere; “Mardin, Şanlıurfa, Adıyaman, Siirt (Eruh, Pervani), Şırnak ve Bitlis'te" (Atalayer, 2002:8) Şel şepik kumaşı dokunmaktadır.

"Geçmişte Bitlis, Muş, Siirt, Şırnak, Hakkâri-Şemdinli, Batman-Sason ve VanBahçesaray'da üretilen Gej dokuması, bölgenin erkek giyiminde elbiselik kumaş olarak 
kullanılmıştı"” (Çelebi, 2002:40). Günümüzde bu kıyafetin dikiminde kullanılan el dokuması kumaşın yerine hazır kumaşlar kullanılmaktadır.

Yine Şel şepik kumaşı ile ilgili çalışmalar incelendiğinde daha çok Bitlis, Siirt ve Şırnak gibi illerde yapılan dokuma araştırma konusu olarak belirlendiği saptanmıştır. Şel şepik sadece bu illerde değil aynı zamanda Hakkâri'de de geçmişte üretilen, günümüzde ise halen elbiselik kumaş için kullanılan dokumalardır.

Çalışma konusu olarak Hakkâri'de tespit edilen Şel şepik Örnekleri belirlenmiştir. Hakkâri'de giyilen geleneksel erkek kıyafeti Şel şepik'in günümüze kadar gelen tarihi gelişimi, geleneksel yönleri, kullanım amacı, kıyafetlerin üretiminde kullanılan hammadde, tezgâh tipi ve renk ve desen zenginliği tespit edilerek yörede gün geçtikçe önemini kaybeden bu kıyafetin gelecek nesillere aktarılması amaçlanmıştır.

Alan araştırmasında Hakkâri merkezindeki Bulak, Tekser, Dağgöl, Gazi mahallelerinde, Kırıkdağ, Çanaklı, Yağmurlu, Bağışlı, Çimenli ve Üzümlü, Durankaya köylerinde, Çukurca ilçesi merkezi, Çı̆̆ılı, Üzümcü ve Köprülü köylerinde, Yüksekova merkeze gidilerek evlerinde Şel şepik kıyafeti bulunan, geçmişte dokumayı yapan ve halen kullanan kişiler tespit edilmiş ve yörede bu kıyafeti giyen kişiler ile sözlü görüşme yapılmıştır. Çalışma kapsamında, Namık Boyar Koleksiyonunda yer alan Şel şepik örnekleri değerlendirilmiştir.

\section{2. Şel Şepik}

Hakkâri'de halkın ihtiyacını karşılamak için halı, kilim gibi dokumalar dışında geçmiş yıllarda mekikli dokumalarda yapılmıştır. Şel ve şepik kıyafetinin dikiminde tercih edilen kumaş da bu dokumalardan biridir. Doğu ve Güneydoğu Anadolu bölgelerinde bu kıyafetin dikiminde kullanılan el dokuması kumaşa "Gej” denilmektedir. Hakkâri'de bu kumaşın yöresel bir adı yoktur. Ancak "Diyar işi, Şırnak işi olarak tanımlanan Şeli şepikler çevrede dokunmaktadır" (Hakkari'98, 1998:88).

Araştırma kapsamında Hakkâri'de yapılan sözlü görüşmelerde bu kumaşa Şel şepik kumaşı denildiği tespit edilmiştir. Geçmişte bu kumaştan dikilen giysiler genellikle halen Hakkâri'nin güney ve batısında daha çok giyilmektedir. Merkez ve diğer yerlerde ise mahalli günler dışında pek giyilmemektedir (Hakkari'98, 1998:88), (Görsel 1). 


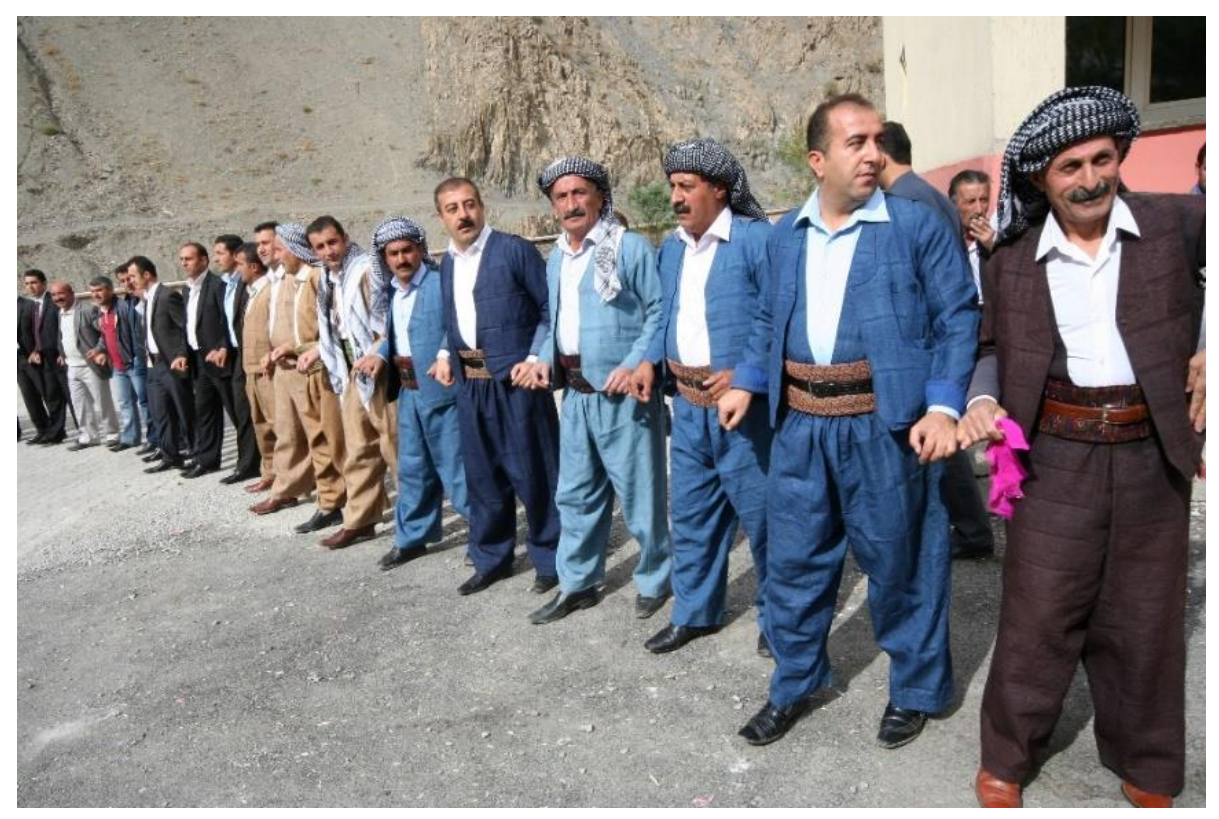

Görsel 1. Şel Şepik Kıyafeti, Fotoğraf: Murat Adıyaman, Hakkâri, 2015.

Günümüzde ise il merkezinde ve diğer yerleşim yerlerinde özel günler (düğün, cenaze törenleri) ve halk oyunları dışında çok fazla kullanılmadığı görülmüştür. Geçmişte Şel şepik yapımında kullanılan kumaş Hakkâri'de kadın ve özelliklede erkekler tarafından çukur tezgâhta dokunan kumaştan üretilmekteydi. Günümüzde yerli ya da Irak'tan temin edilen hazır kumaşlardan dikilmektedir. Hakkâri'nin merkezinde birkaç terzi bu kıyafetin dikimi ile uğraşmaktadır.

Yapılan sözlü görüşmelerde Hakkâri ili ve çevresinde bulduğumuz en eski örneğin "1875 yılına ait olduğu ve erkek kıyafetlerin dikiminde kullanılan kumaşın 1960 yılına” kadar (Boyar, Sözlü Görüşme:2015) ve "Tiyar deresi kırsalında erkek dokuyucular tarafından çukur tezgâhlarda bu kumaşın dokunduğu" (Özkahraman, Sözlü Görüşme:2021) şeklinde bilgiler elde edilmiştir.

Şel şepik kıyafeti iki parçadan oluşmaktadır. Şel alt, şepik üst beden giysisine verilen isimdir. "Yerel erkek kıyafetleri Şel-şepik (Şelüşepik) denen günlük kıyafetlerdir" (Yalçın, 2011:165). 
Şel: Hakkâri'de erkeklerin pantolon yerine giydikleri kıyafetin yöresel ismidir. "Şalvarda denilen, kemer yerine lastik kullanılan, bacak arasından itibaren genişleyen ancak paçaları daralan, ütü yeri belli olmayan pantolondur" (Yalçın, 2011:165).

İlgili kaynaklarda ve yörede şalvar olarak da adlandırılan bu giysi türü, bel yani uçkur kısmına kemer takmak yerine saç örgüsü olarak yapılan ip geçirilerek giyilen, bel ve kalça bölümü geniş ölçülerde, paça kısmı ise gittikçe daralarak kesilip dikilerek kullanılmaktadır. Aynı zamanda paça kısmı bol olarak dikilen örnekleri de mevcuttur (Görsel 2).
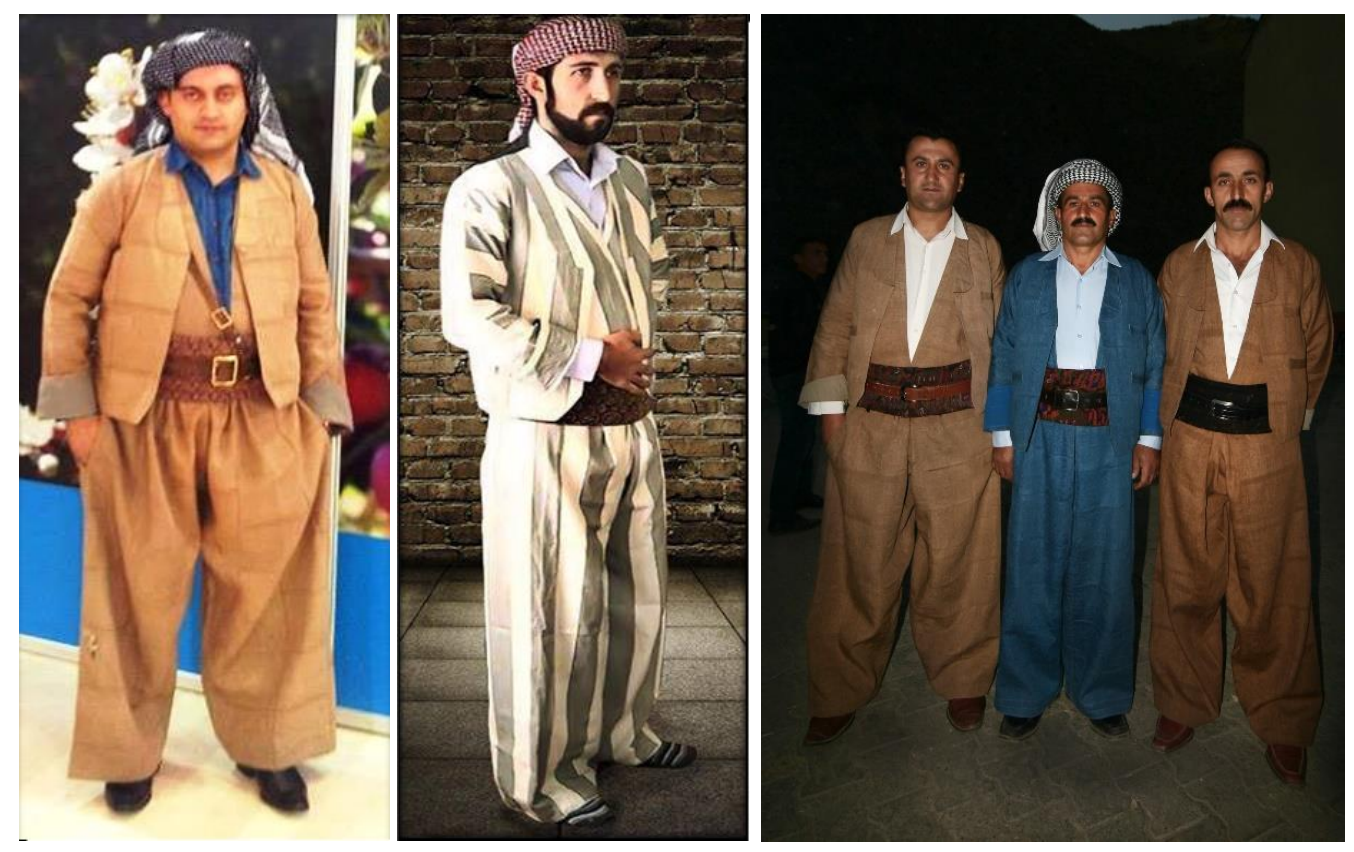

Görsel 2. Şel Şepik Kıyafeti, Fotoğraf: Celal Adıyaman, Münir Beyter, Murat Adıyaman, Hakkâri, 2015.

Şepik: Hakkâri'de erkeklerin gömlek yerine giydikleri kıyafetin yöresel ismidir. Şel şepik kıyafetinin en belirgin özelliği aynı renk ve kalitedeki kumaştan dikilmesidir. Şepik, boyu kalça hizasında, uzun kollu ve kolları düğmesiz, hâkim yakalı giysidir.

Bazı eski kıyafet örneklerinde dikildikten sonra yaka, kol ve ön yüzlerine süsleme olarak renkli ipliklerle işleme yapılarak kullanılmaktadır. Şepik kıyafetinin koltuk altı kısmında dikiş sırasında yaklaşık $7 \mathrm{~cm}$. uzunluğunda boşluk bırakılmaktadır. Bu boşluk kolun daha rahat hareket etmesini sağlamak ve terlemeyi önlemesi içindir. 
Şel şepik kıyafeti için tercih edilen kumaş geçmişte yünün doğal rengi olan beyaz renk ip ile dokunmaktadır. Dokunan kumaş Şel şepik kıyafeti isteyen kişinin beden ölçülerine göre kesilip dikilmektedir. Dikilen Şel şepik kıyafetlerinin kol, yaka ve paça kısımları dokuma ve dikiş sonrası işleme tekniği ile süslenmekteydi. Bu süslemelerin bazıları dokuma esnasında renkli iplik gruplarıyla da yapılmaktaydı. Bu işlemeler erkek kıyafetinin her iki paçası üzerinde yaklaşık 3-4 cm. genişliğinde sabitlenmiştir. Yörede işlemeli Şel şepik örnekleri eski dönemlerde daha çok düğün gibi özel günler için tercih edilmektedir. Bu kıyafetlerin "kumaşları veya süsleri maddi duruma göre ipek, kadife ya da yünden olup üzerleri gümüşlerle ya da simlerle süslenmektedir. Kıyafetin bel kısmına şal bağlanmakta ve onun üstüne de kayış takılmaktadır" (Taş, 2014:66), (Görsel 3).

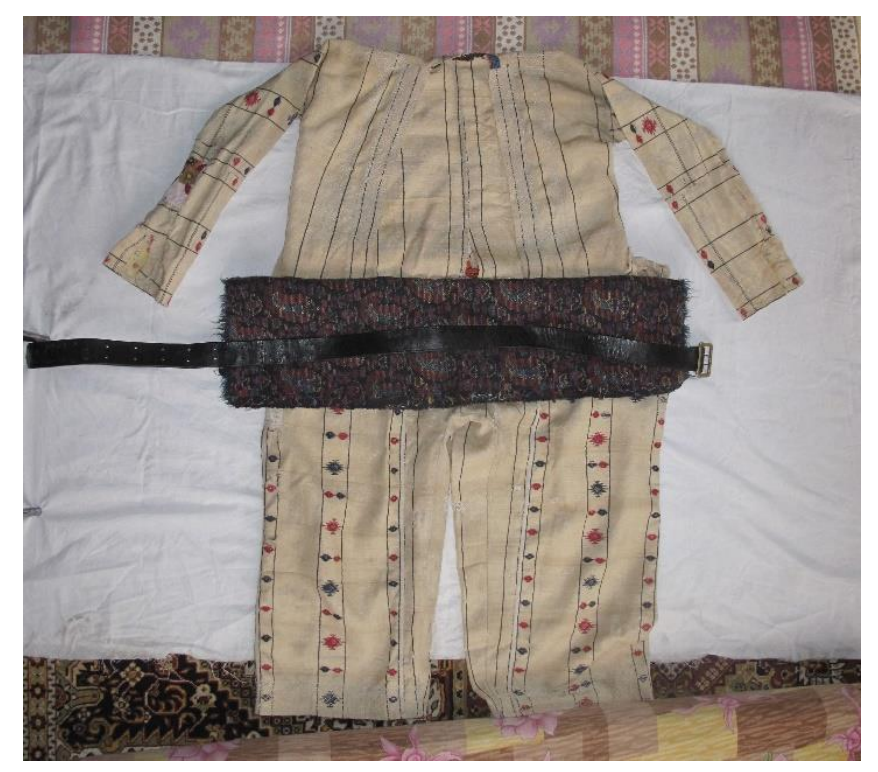

Görsel 3. Özel Günlerde Giyilen Şel Şepik Kıyafeti, Fotoğraf: Illker Öztürk, Hakkâri, 2015.

Araştırma kapsamında işlemeli örneklerden biri 2015 yılında sadece Çukurca ilçesinde tespit edilmiştir. Burada yapılan sözlü görüşmede, "geçmiş dönemlerde Çukurca'da yaşayan 4 Yahudi tüccarın bu işle uğraştıkları” bilgisine ulaşılmıştır (Kuşar, Sözlü Görüşme:2015). Bu dokumalardan elde edilen erkek kıyafeti içine üst bedene iç çamaşırı olarak tercih edilen renkli kadife ya da basma kumaştan dikilmiş gömlekler ve alt kısmına da hassa kumaşından yapılmış uzun donlar giymektedirler. İç kısma giyilen gömleklerin kollarına levendi denilen parçalar eklenmektedir. Levendi parçaları el bileği üzerine sarılı şekilde kullanılmaktadır. İş yapılırken bu 
levendiler düğümlenerek boyun arkasına atılır ve yöresel oyunlar oynanırken aşağı doğru sarkık bırakılmaktadır. Açıklanan alt ve üst beden giysilerin üzerine yörede şal denilen kuşaklara benzer yer tezgâhında dokunan el dokuması parçalar sarılarak bağlanmaktadır (Görsel 4).

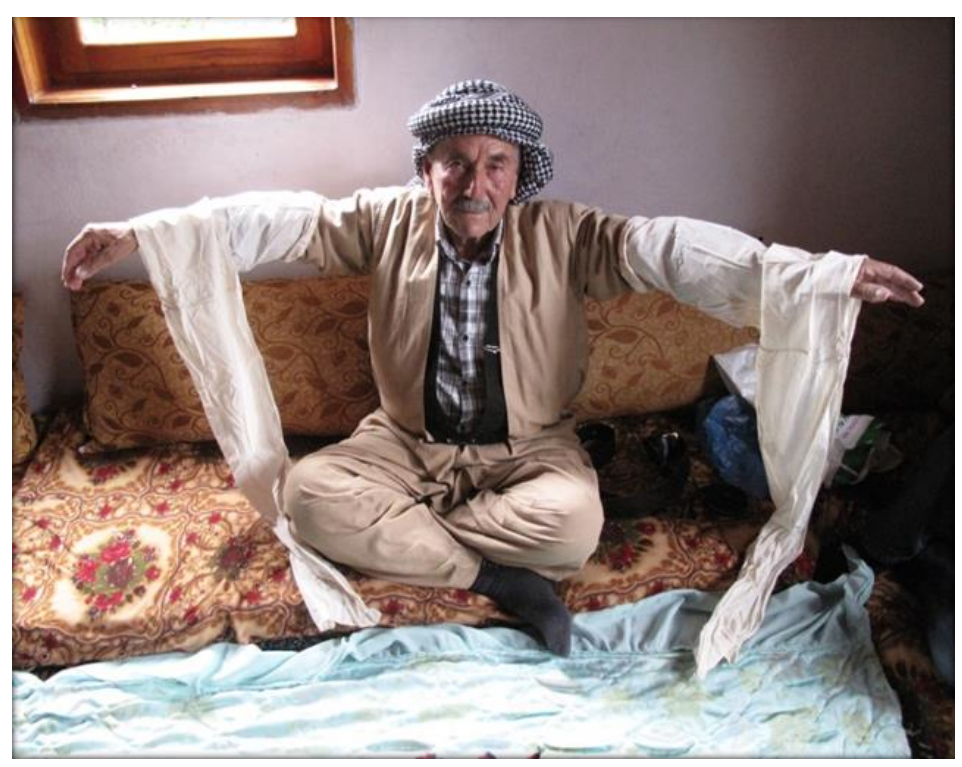

Görsel 4. Şel Şepik Kıyafeti, Fotoğraf: ilker Öztürk, Çı̆̆lı Köyü, Hakkâri, 2015.

\section{3. Şel Şepiklerin Teknik Özellikleri}

$\mathrm{Bu}$ bölümde Şel şepik kıyafetlerin üretiminde kullanılan hammadde, yapımında kullanılan tezgâh tipi, dokuma tekniği, renk ve desen özellikleri gibi bilgilere yer verilmiştir.

Hammadde: Şel şepik kumaşının yapımında tiftik keçisinden elde edilen iplik hammadde olarak kullanılmaktadır. Tiftik keçisinden elde edilen kıllar "yıkanıp kurutulduktan sonra yörede "şek" adı verilen taraklarda taranır. Teşi ile oldukça ince bir şekilde tek kat olarak eğrilen ipler, dolap denilen tahta sargılarla iki veya üç kat halinde bükülür ve çile tabir edilen yumaklar haline getirilir" (Çelebi, 2002:40). Yapılan sözlü görüşmede eğirme işleminin sadece teşi ile yapılmadığı anlaşılmıştır. Yöre kadınlarının eğirme işlemi için başparmaklarının tırnağını uzatarak bunun ortasına küçük bir delik açtıkları ve lifleri buradan geçirerek işlemi gerçekleştirdikleri bilgisi elde edilmiştir. Delik ne kadar küçük olursa tiftik ipi o kadar güzel, ince, kaliteli ve bükümü iyi olmaktadır. 
SDÜ ART-E

Güzel Sanatlar Fakültesi Sanat Dergisi

Haziran'21 Cilt:14 Sayı:27

ISSN 1308-2698

Eğirme işleminin kadınlar tarafından "tiftik kılı başparmağın tırnağının ortasındaki küçük bir deliğin içinden kılın geçirilmesi ile" yapıldığı belirtilmiştir. Bu şekilde daha ince bir ip elde edilmekteydi. İncelik dokuma kumaşın daha kaliteli olmasını sağlamaktaydı (Garipgazioğlu, Sözlü Görüşme:2015). Çözgü ve atkı ipi tiftik keçisinin doğal rengi olan siyah, beyaz, sarımtırak ve kahverengi olarak kullanılmaktaydı. Desen ipliği ise sentetik boyalar ile boyanmışlardır. Günümüze yakın tespit edilen kumaşlar ise tamamen kimyasal olarak sentezlenen boyalar ile renklendirilmektedir.

Tezgâh: Şel şepik kıyafetinin dikiminde kullanılan kumaş geçmiş dönemlerde ağaçtan yapılan çukur tezgâhta dokunmaktaydı. Çukur tezgâh “Anadolu'da görülen bir tezgâh tipidir. Bunlara çukur tezgâh denmesinin sebebi, dokumacının oturduğu ve pedallarının bulunduğu kısım bir çukur içerisinde olmasındandır" (Yağan, 1978:193). Hakkâri'de bu dokuma daha çok erkekler tarafından yapılmaktadır. Yapılan alan araştırmasında çukur tezgâh ve parçalarına rastlanılmamıştır. Bu tezgâh; "iki gücülü, iki ayaklı ve mekikli çukur tezgâhlardır” (Çelik, 2006:344). 1980'den sonra yörede kamçılı tezgâhta dokumalar yapıldığı saptanmıştır. Günümüzde mekikli dokumacılık yapılmamaktadır.

Çözgü İ̧̧lemi: Çözgü boyu dokuyucunun istediği uzunlukta ayarlanmaktaydı. En ve boya göre hazırlanan çözgü ipleri çukur tezgâh üzerine aktarılarak, gücü iplerinden ve taraktan geçirilerek gergin olacak şekilde bağlanmaktaydı.

Dokuma Tekniği: Şel şepik kumaş dokuması bez ayağı örgüsü ile tek ya da iki renk, günümüz örneklerinde ise tek renk dokunmaktadır. "Çözgü ipliklerin rengi ile atkı ipliklerin rengi aynı olmaktadır. Fakat istenilen kumaş desenine göre, yatay olan çizgiler farklı renkte atkı ipliği kullanılarak elde edilmektedir. Eğer dokumada iki renk kullanılıyorsa, iki mekik, beş renk kullanılıyorsa beş mekik kullanılmaktadır. Yani her renk için ayrı atkı ipliği ve mekik kullanılmaktadır" (Yıldırım, 2013:116).

Renk ve Desen Özelliği: Şel şepik kumaşının dokumasında kullanılan ipin renkleri yörede yetişen tiftik keçisinden elde edilen iplerin doğal rengi olan siyah, beyaz ve kahverengidir. İlk dokunan kumaşlarda daha çok beyaz renk tercih edilmekteydi. Yakın süreçte dokunan kumaşların yapımında çözgü ipi olarak daha çok mavi, krem ve kahverengi renklerin kullanımı 
görülmektedir. Kumaşların zeminleri belli aralıklarla kalın ve ince çizgilerden oluşan desenler ile düzenlemektedir. Bazı Şel şepik kumaşının hem siyah, beyaz dikine hem de yatay çizgili desenden oluştuğu görülmektedir (Görsel 5).

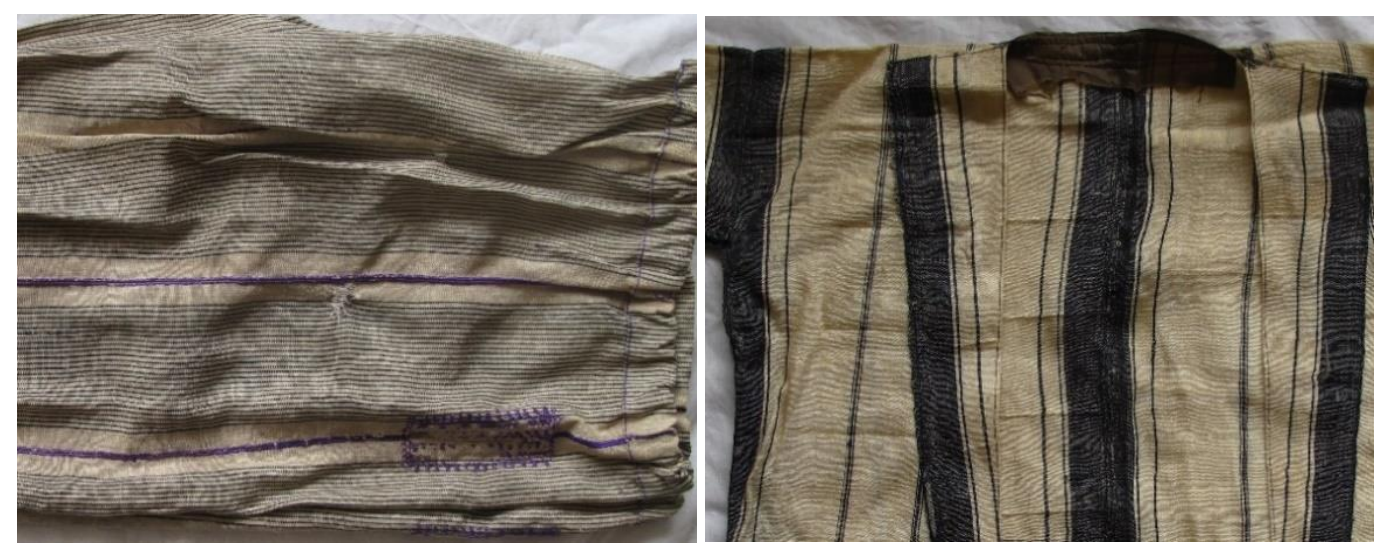

Görsel 5. Şel (Pantolon) ve Şepik (Gömlek) Kıyafeti.

Eski örnekler üzerinde renkli iplikler kullanılarak yapılmış işlemeler bulunmaktadır. İşlemeler genellikle alt alta ya da yan yana sıralanarak uygulanmıştır. Kumaştaki desenler dokuma esnasında verilmekteydi. Şel giysisinin paça kısımlarında ve cep kenarlarında yer alan süslemelerin bazılarının dokuma esnasında yapılan motiflerin olduğu, bazılarının ise dokuma işlemi sonrasında $2-3 \mathrm{~cm}$. ölçülerinde yapıldığı belirlenmiştir. Aynı işlemler şepiklerin de yaka, ön yüz ve kol ağzı kenarlarında yaklaşık $2-3 \mathrm{~cm}$. ölçülerinde uygulandığı görülmektedir (Görsel 6).
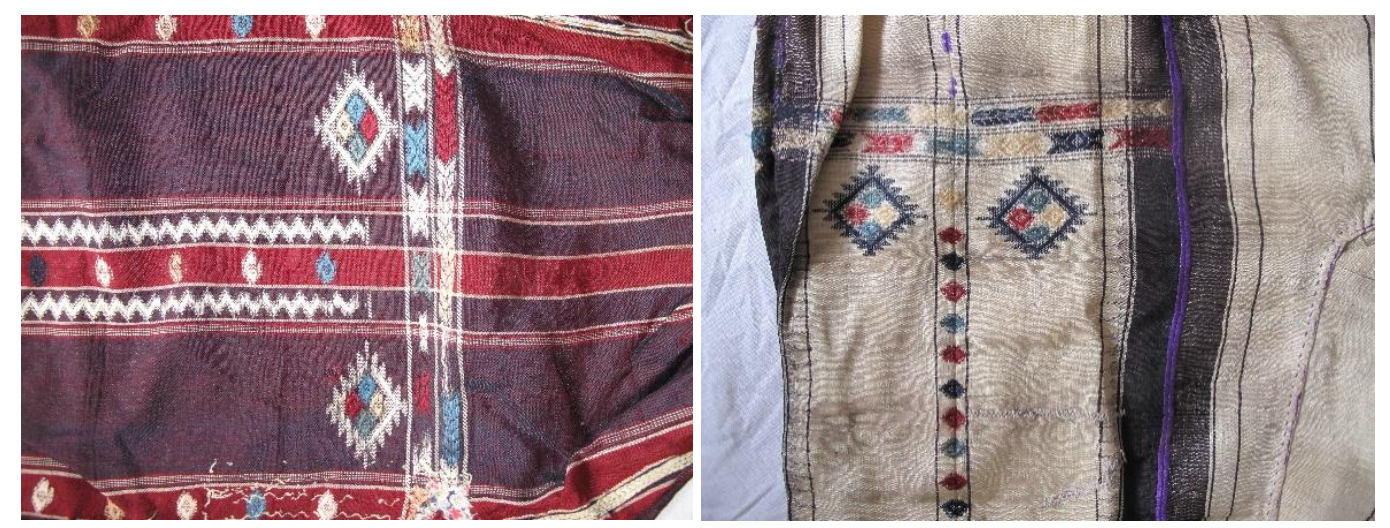

Görsel 6. Şel (Pantolon) Kıyafeti Motif Detay, Namık Boyar Koleksiyonu, Fotoğraf: IIlker Öztürk, Hakkâri, 2015. 


\section{4. Şel Şepik Örnekleri}

Bu kısımda Hakkâri'de tespit edilen Şel şepik örneklerinden 3 şepik (gömlek), 2 şel (pantolon) toplam 5 tanesine ait fotoğraflar ve bu giysilerin bazı özellikleri birlikte verilmiştir.

\section{Örnek 1.}
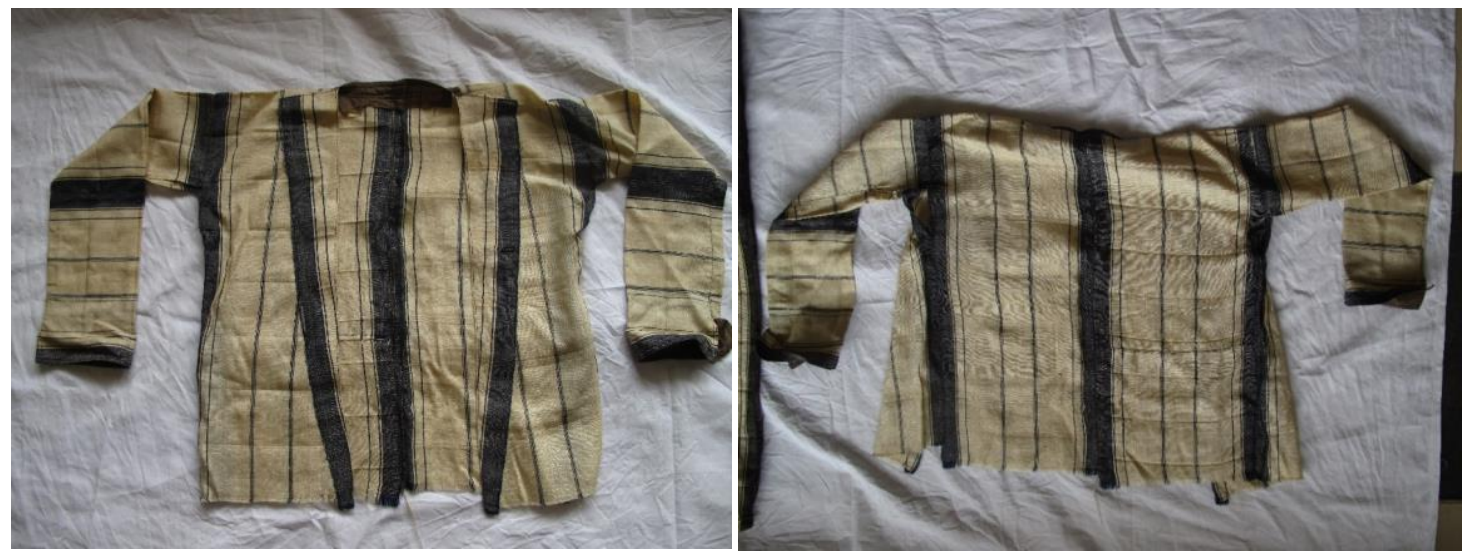

Görsel 7. Şepik (Gömlek) Giysisi Ön ve Arka Yüzü, Namık Boyar Koleksiyonu, Fotoğraf: İlker Öztürk, Hakkâri, 2015.

Inceleme Tarihi: 01.05.2015

Tespit Edildiği Yer: Namık Boyar, Merkez, Hakkâri

Dokuyucu: -

Tarihlendirme: 140 Yıl (Yaklaşık)

Yöresel Adı: Şepik

Kullanım Alanı: Üst beden giysisidir.

İplik Türü (Atkı x Çözgü x Desen): Tiftik

Dokuma Tekniği: Bez ayağı

Tezgâh Tipi: Çukur Tezgâh

Renk: Siyah, Beyaz

En x Boy Ölçüsü: 65 cm. x 20 cm. (Tek Parça)

Kol Ağzı Ölçüsü: 16 cm. 
Kol Uzunluğu Ölçüsü: 55 cm.

Yaka Ölçüsü: $18 \mathrm{~cm}$.

Omuz Genişliği Ölçüsü: $55 \mathrm{~cm}$.

Motif ve Desen Özelliği: Şepik kumaşın zemini, dikine birbirine paralel belirli aralıklar içinde ince ve kalın çizgiler oluşan kompozisyon deseni ile düzenlenmiştir. Bu çizgiler zeminde siyah ve beyaz renklerden oluşan sade bir görünüme sahiptir. Kumaşın deseni dokuma esnasında yapılmıştır. Şepik örneğinin koltuk altı kısmında yaklaşık $7 \mathrm{~cm}$. ölçüsünde yırtık şeklindeki boşluk dikilirken bırakılmıştır. Bu açıklık rahat hareketi ve terlemeyi önlemek için yapılmıştır (Görsel 7).

\section{Örnek 2.}

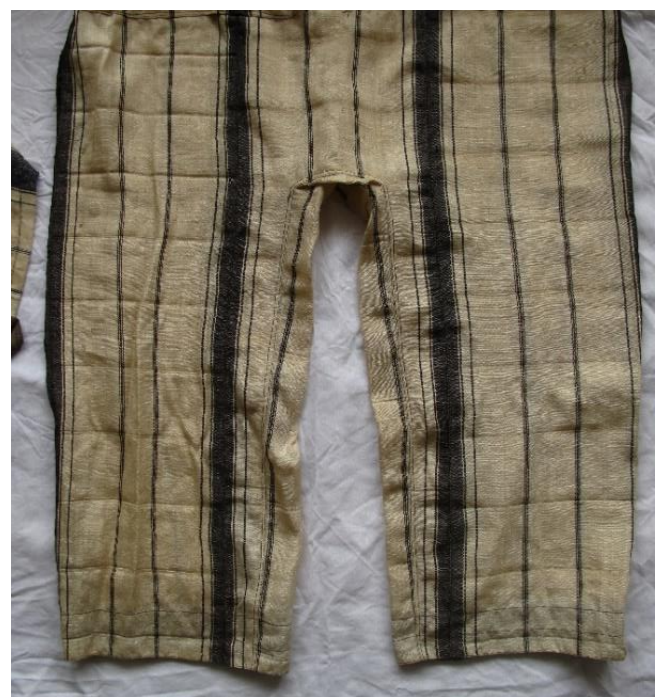

Görsel 8. Şel (Pantolon) Alt Beden Giysisi, Namık Boyar Koleksiyonu, Fotoğraf: Illker Öztürk, Hakkâri, 2015.

İnceleme Tarihi: 01.05.2015

Tespit Edildiği Yer: Namık Boyar, Merkez, Hakkâri

Dokuyucu: -

Tarihlendirme: 140 Yıl (Yaklaşık)

Yöresel Adı: Şel

Kullanım Alanı: Alt beden giysisidir. 
İplik Türü (Atkı x Çözgü x Desen): Tiftik x

Dokuma Tekniği: Bez ayağı

Tezgâh Tipi: Çukur Tezgâh

Renk: Siyah, Beyaz

Bel x Boy Ölçüsü: $150 \mathrm{~cm}$ x $90 \mathrm{~cm}$.

Cep Ölçüsü: 16 cm.

Paça Genişlik Ölçüsü: 35 cm.

Ağ Ölçüsü: $60 \mathrm{~cm}$. (Tek Parça)

Motif ve Desen Özelliği: Şel kumaşın zemini, dikine birbirine paralel belirli aralıklar içinde ince ve kalın çizgiler oluşan kompozisyon deseni ile düzenlenmiştir. Bu çizgiler zeminde siyah ve beyaz renklerden oluşan sade bir görünüme sahiptir. Kumaşın deseni dokuma esnasında yapılmıştır (Görsel 8).

\section{Örnek 3.}
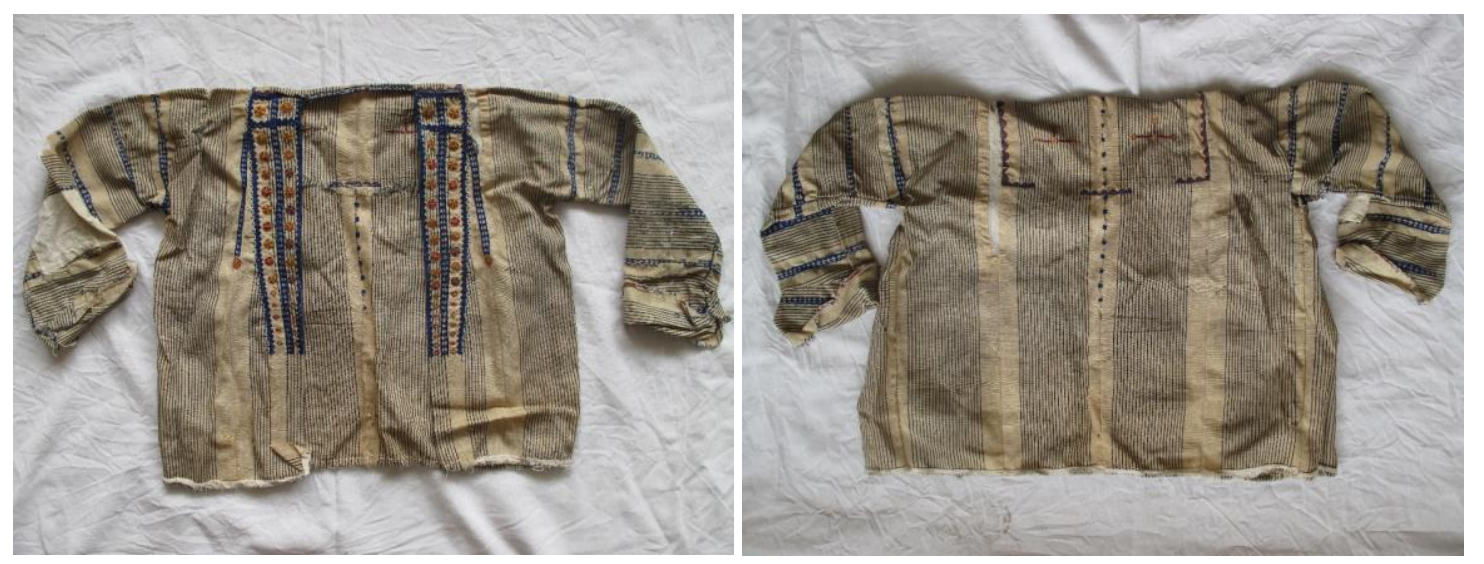

Görsel 9. Şepik (Gömlek) Giysisi Ön ve Arka Yüzü, Fotoğraf: İlker Öztürk, Hakkâri, 2015.

Inceleme Tarihi: 20.05.2015

Tespit Edildiği Yer: Namık Boyar, Hakkâri

Dokuyucu: - 
Tarihlendirme: 120 Yll

Yöresel Adı: Şepik

Kullanım Alanı: Üst beden giysisidir.

İplik Türü (Atkı x Çözgü x Desen): Tiftik

Dokuma Tekniği: Bez ayağı

Tezgâh Tipi: Çukur Tezgâh

Renk: Siyah, Beyaz, Mavi, Turuncu

En x Boy Ölçüsü: 53 cm. (28,5 Tek Parça) x 65 cm. (Arka ve Ön)

Kol Ağzı Ölçüsü: 17 cm.

Kol Uzunluğu Ölçüsü: 44 cm.

Kol Manşet Ölçüsü: -

Yaka Ölçüsü: 16 cm.

Omuz Genişliği Ölçüsü: 57 cm.

Arka Yırtmaç Ölçüsü: -

Motif ve Desen Özelliği: Şepik kumaşın zemini, beyaz ve mavi dikine birbirine paralel belirli aralıklar içinde ince ve kalın çizgiler oluşan kompozisyon deseni ile düzenlenmiştir. Zemindeki çizgiler iki ya da üç mm. aralığında birbirine paralel siyah çizgiler ve iç kısmında ise beyaz çizgiler yer almaktadır. Kumaşın deseni dokuma esnasında yapılmışır. Erkek kıyafetinin ön iki yüzünde, yaka çevresinde ve kolları işleme yapılarak süslenmiştir. Şepik örneğinin koltuk altı kısmında yaklaşık $7 \mathrm{~cm}$. ölçüsünde yırtık şeklinde boşluk dikilirken bırakılmıştır (Görsel 9). 


\section{Örnek 4.}

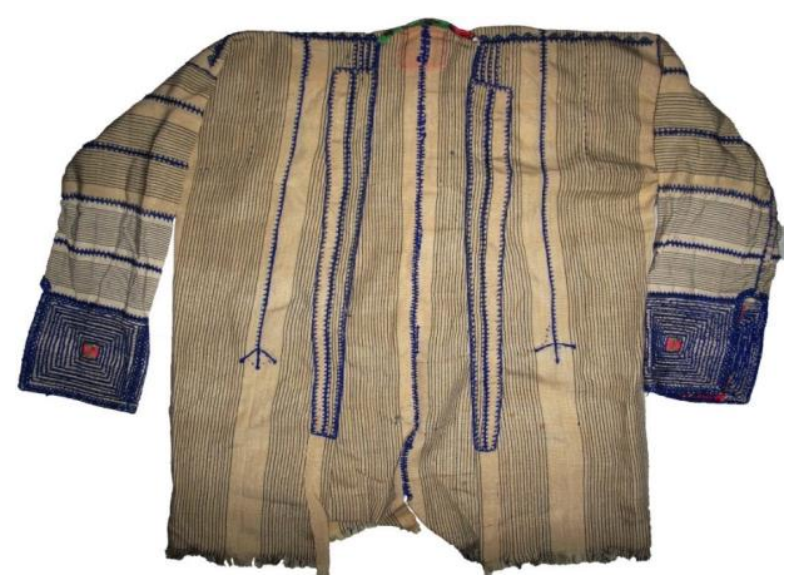

Görsel 10. Şepik (Gömlek) Giysisi Ön Yüzü, Fotoğraf: Illker Öztürk, Çukurca, Hakkâri, 2015.

Inceleme Tarihi: 20.05.2015

Tespit Edildiği Yer: Muşatti Kuşar, Çukurca, Hakkâri

Dokuyucu: Enwark (Yahudi bir Dokuyucu), (Kuşar, Sözlü Görüşme:2015)

Tarihlendirme: 120 Yıl

Yöresel Adı: Şepik

Kullanım Alanı: Üst beden giysisidir.

İplik Türü (Atkı x Çözgü x Desen): Tiftik

Dokuma Tekniği: Bez ayağı

Tezgâh Tipi: Çukur Tezgâh

Renk: Siyah, Beyaz, Mavi

En x Boy Ölçüsü: $23 \mathrm{~cm}$. (Tek Parça), $65 \mathrm{~cm}$ x $71 \mathrm{~cm}$. (Arka ve Ön)

Kol Ağzı Ölçüsü: 30 cm.

Kol Uzunluğu Ölçüsü: 46 cm. 
Kol Manşet Ölçüsü: $12 \mathrm{~cm}$.

Yaka Ölçüsü: $22 \mathrm{~cm}$.

Omuz Genişliği Ölçüsü: 23 cm.

Arka Yırtmaç Ölçüsü: $7 \mathrm{~cm}$.

Motif ve Desen Özelliği: Şepik kumaşın zemini, dikine birbirine paralel belirli aralıklar içinde ince ve kalın çizgiler oluşan kompozisyon deseni ile düzenlenmiştir. Zemindeki bu çizgiler geniş olanının iç kısmında iki ya da üç milim sık aralıklar ile dikine birbirine paralel siyah çizgiler, dar olanının iç kısmında ise beyaz ve mor çizgi yer almaktadır. Kumaşın deseni dokuma esnasında yapılmıştır. Erkek kıyafetinin ön iki yüzünde, yaka çevresinde ve kollarında $15 \mathrm{~cm}$. genişliğinde mavi renk ip kullanılarak estetik açıdan güzellik katmak için işleme yapılarak süslenmiştir. Şepik örneğinin koltuk altı kısmında yaklaşık $8 \mathrm{~cm}$. ölçüsünde yırtık şeklinde boşluk dikilirken bırakılmıştır (Görsel 10).

\section{Örnek 4.}

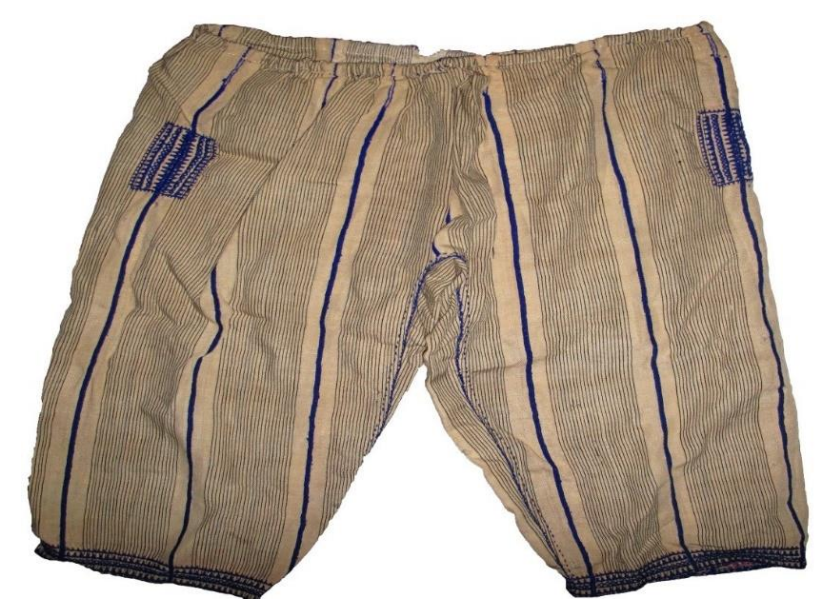

Görsel 11. Şel (Pantolon) Giysisi Ön Yüzü, Fotoğraf: İlker Öztürk, Çukurca, Hakkâri, 2015.

İnceleme Tarihi: 20.05.2015

Tespit Edildiği Yer: Muşatti Kuşar, Çukurca, Hakkâri

Dokuyucu: Enwark (Yahudi bir Dokuyucu), (Kuşar, Sözlü Görüşme:2015)

Tarihlendirme: 120 Yll 
Yöresel Adı: Şel

Kullanım Alanı: Alt beden giysisidir.

İplik Türü (Atkı x Çözgü x Desen): Tiftik x

Dokuma Tekniği: Bez ayağı

Tezgâh Tipi: Çukur Tezgâh

Renk: Siyah, Beyaz, Mavi

Bel x Boy Ölçüsü: 350 cm. x 91 cm.

Cep Ölçüsü: 15 cm.

Paça Genişlik Ölçüsü: 58 cm.

Ağ Ölçüsü: 59 cm. (Tek Parça)

Motif ve Desen Özelliği: Şel kumaşın zemini, dikine birbirine paralel belirli aralıklar içinde ince ve kalın çizgiler oluşan kompozisyon deseni ile düzenlenmiştir. Cep kısmı yapılmamıştır. Erkek kıyafetinin iki paçasının çevresi yaklaşık $3 \mathrm{~cm}$. genişliğinde ve cep kısmı mavi renkli ip ile işleme yapılarak süslenmiştir. Kumaşın deseni dokuma esnasında yapılmıştır (Görsel 11).

\section{Sonuç}

Nesilden nesile aktarılan sözlü ve folklorik kültürel öğelerden oluşan somut olmayan kültürel miras unsurları, somut kültürel miras öğeleri ve dokumalar tarihsel süreç içerisinde geçiş evreleri yaşamakta, çevreden doğadan ve tarihten etkilenerek yeniden şekil almaktadır. Kullandıkça tekrarlanmış, gelişmiş ve bugüne kadar gelmiş, atalardan miras kalmış olan değerli kültür, son döneme kadar büyük oranda korunmuş ve yaşatılmıştır (Genç vd, 2019:14).

"Ülkemizde el dokumaları, yöre özelliklerine ve ihtiyaçlarına göre birbirinden farklı şekillerde üretilebilmekte, bu farklılık ile zenginlikte, yörenin doğal yapısı, geleneksel yaşam biçimi ve ekonomisi etkili olmaktadır" (Çelebi, 2002:39).

Bu dokumalardan birisi Şel şepik kumaşıdır. Şel şepik Doğu ve Güneydoğu Anadolu bölgelerinde erkeklerin giydikleri geleneksel bir kıyafettir. Bu kıyafet iki parçadan oluşmakta ve 
birlikte giyilmektedir. Şel pantolona, şepik ise gömleğe verilen yöresel isimdir. Geçmişte Şel şepik kumaşının yapımında çözgü ve atkıda tiftik keçisinden elde edilen iplik kullanıldı̆̆ı, günümüzde hazır temin edilen kumaşlarda ise tamamen sentetik ipin kullanıldığı belirlenmiştir. Kumaşın çukur tezgâhlarda dokunduğu saptanmıştır.

Günümüzde yapılan araştırmada çukur tezgâh ya da bir parçasına rastlanılmamıştır. Fakat yapılan sözlü görüşmelerde bu dokumanın Hakkâri'de Tiyar deresi kırsalında ve Çukurca'da yapıldığı bilgisine ulaşılmıştır. Hakkâri'de önemini kaybeden kumaş dokumacılığı Siirt ve Şırnak illerinde kısmen de olsa devam etmektedir. Günümüzde eski örneklerden daha çok sade görünüme sahip, kahverengi ve mavi tonlarında dikilen kumaştan olan Şel şepiklerin giyildiği görülmüştür.

Günümüzde birçok belediye meslek edindirme kursları veya sanat etkinliği adı altında geleneksel sanat dallarıyla ilgili kurslar düzenlemektedir. 10 yıl öncesine göre bu sanatların bilinirliği artmıştır. Ama özden uzaklaşılmıştır. Geleneksel üretimler geçmişte estetik unsurun yanında işlevsel yönüyle de ön planda idi. Dokuma ve diğer alanlar estetik unsur olmanın yanında kullanım alanı ile değerlendirilmelidir (Genç, 2015:152).

\section{Teşekkür}

Yazar bu çalışmada Namık Boyar’a, Murat Adıyaman'a, Enver Özkahraman'a, Asiye Akdağ’a vermiş olduğu bilgilerden ve yardımlardan dolayı teşekkürü bir borç bilirim. 


\section{Kaynakça}

\section{-Kitap}

Hakkâri’98, (1998). Hakkâri il Yıllığı, Hakkâri, T.C. Hakkâri Valiliği.

Tan, N. (1992). Folklorik Türk Kıyafetleri: Turkish Folkloric Costumes, Ankara, Türkiye Güzel Sanatları Geliştirme Vakfı Yayınları.

Taş, E. (2014). Van El Sanatları, Van, T. C. Van Valiliği, Yüzüncü Yıl Üniversitesi, Funda Ajans.

Yağan, Ş.Y. (1978). Türk El Dokumacılığı, İstanbul, Türkiye İş Bankası Kültür Yayınları.

Yalçın, H. (2011). Hakkâri, Hakkâri, T.C. Hakkâri Valiliği Yayın No: 6.

\section{-Makaleler}

Genç, M, Şimşek Tolacı, S. (2019). Sarıkeçili Yörüklerinde Toplumsal Uygulamalar ve MekânIsparta Atabey-Gönen Örnekleri, Art-e Sanat Dergisi, Özel Sayı, 1-15. DOI: 10.21602/sduarte.638797.

Genç, M., Tezcan, V. (2015). Gelenek ve Yenilik Kavramlarının Felsefesi Tartışması Ekseninde Geleneksel Türk Sanatlarını Yeniden Düşünmek, Kalemişi Dergisi, C.3, S.6.

\section{-Tezler}

Öztürk, ì. (2014). Hakkâri ve Çevresinde Bulunan Havsız Kirkitli Dokumalar, Yayımlanmamış Yüksek Lisans Tezi, Erzurum: Atatürk Üniversitesi, Sosyal Bilimler Enstitüsü, Geleneksel Türk El Sanatları Ana Sanat Dalı.

Yıldııım, Ş. (2013). Şırnak Yöresi Şal Şapik Kumaş Dokumacılığı, Yayımlanmamış Yüksek Lisans Tezi, Ankara: Gazi Üniversitesi, Eğitim Bilimleri Enstitüsü El Sanatları Eğitimi Anabilim Dalı Dokuma - Örgü Eğitimi Bilim Dalı.

\section{-Bildiriler}

Akpınarlı, F. ve Ortaç, S. (2007). "Ankara Çubuk ilç̧esi Çarpana Dokumaları", I. Uluslararası Türk El Dokumaları Kongresi Bildirileri, Konya: Selçuk Üniversitesi, Selçuklu Araştırma Merkezi Başkanlığı Yayınları, s. 80-85.

Atalayer, G. (2002) "Güneydoğu Anadolu'dan Seçilmiş Dokumalar Üzerine Öneriler", Gap Çerçevesinde Halk Kültürü Sempozyumu Bildirileri (Gaziantep-2001), Ankara: T. C. Kültür Bakanlığı Yayınları: 2957, Halk Kültürleri Araştırma ve Geliştirme Genel Müdürlüğü Yayınları: 337, Seminer Kongre Bildirileri Dizisi: 73, s. 6-16. 
Çelebi, C. (2002). "Yok Olmaya Yüz Tutmuş Bir El Sanatı: Şal-Şapik (Gej) Dokuma", Gap Çerçevesinde Halk Kültürü Sempozyumu Bildirileri (Gaziantep-2001), Ankara: T. C. Kültür Bakanlığı Yayınları: 2957, Halk Kültürleri Araştırma ve Geliştirme Genel Müdürlüğü Yayınları: 337, Seminer Kongre Bildirileri Dizisi: 73, s. 39-42.

Çelik, A. (2006). "Bitlis Yöresi El Dokumalarında "Gej"in Tanıtımı", Van: I. Van Gölü Havzası Sempozyumu, s. 341-346.

Tansuğ, S. (1977). "Türkmenlerde Giyim Gelenekleri", I. Uluslararası Türk Folklor Kongresi Bildirileri, Ankara: Kültür Bakanlığı Milli Folklor Araştırmaları Dairesi Yayınları: 22, Seminer, Kongre Bildirileri Dizisi: 7, V. Cilt, Etnografya, Akın Matbaası, s. 251-256.

\section{-Görüşmeler}

Boyar, N. (2015). Namık Boyar ile yapılan görüşme, Hakkâri: 1 Mayıs.

Garipgazioğlu, K. (2015). Kadir Garipgazioğlu ile yapılan görüşme, Hakkâri: 7 Haziran.

Kuşar, M. (2015). Muşatti Kuşar ile evinde yapılan sözlü görüşme, Çukurca: 20 Mayıs.

Özkahraman, E. (2021). Enver Özkahraman ile yapılan görüşme, Van: 24 Şubat.

\section{-Görsel Kaynaklar}

Görsel 1. Şel Şepik Kıyafeti, Fotoğraf: Murat Adıyaman, Hakkâri, t.y.

Görsel 2. Şel Şepik Kıyafeti, Fotoğraf: Celal Adıyaman, Münir Beyter, Murat Adıyaman, Hakkâri, 2015.

Görsel 3. Özel Günlerde Giyilen Şel Şepik Kıyafeti, Fotoğraf: Illker Öztürk, Hakkâri, 2015.

Görsel 4. Şel Şepik Kıyafeti, Fotoğraf: Ilker Öztürk, Çığlı Köyü, Hakkâri, 2015.

Görsel 5. Şel (Pantolon) ve Şepik (Gömlek) Kıyafeti Desen Detay, Namık Boyar Koleksiyonu, Fotoğraf: ilker Öztürk, Hakkâri, 2015.

Görsel 6. Şel (Pantolon) Kıyafeti Motif Detay, Namık Boyar Koleksiyonu, Fotoğraf: İlker Öztürk, Hakkâri, 2015.

Görsel 7. Şepik (Gömlek) Giysisi Ön ve Arka Yüzü, Namık Boyar Koleksiyonu, Fotoğraf: İlker Öztürk, Hakkâri, 2015. 
Görsel 8. Şel (Pantolon) Alt Beden Giysisi, Namık Boyar Koleksiyonu, Fotoğraf: İlker Öztürk, Hakkâri, 2015.

Görsel 9. Şepik (Gömlek) Giysisi Ön ve Arka Yüzü, Fotoğraf: Illker Öztürk, Hakkâri, 2015.

Görsel 10. Şepik (Gömlek) Giysisi Ön Yüzü, Fotoğraf: Illker Öztürk, Çukurca, Hakkâri, 2015.

Görsel 11. Şel (Pantolon) Giysisi Ön Yüzü, Fotoğraf: Illker Öztürk, Çukurca, Hakkâri, 2015. 